\title{
Teaching-learning process in times of the Unified Health System (SUS): training of faculty and dental surgeons in Brazil
}

\author{
Processo ensino-aprendizagem em tempos de SUS: adequação \\ docente e formação dos cirurgiões-dentistas no Brasil
}

\begin{abstract}
With the aim of contributing to the current curricular transformation of Brazilian Dentistry courses, this study describes the training of dental surgeons considering the needs of the public Unified Health System (SUS - Sistema Único de Saúde). We focus on the health care model currently in force and emphasize the idea that so as to attain the principles of this model, a shift in the training of instructors who lecture in Dentistry should occur. Some aspects of the training of such instructors, together with the implementation of the National Curricular Guidelines in Dentistry courses, are discussed, and the professional profiles of graduates from Brazilian dental schools are analyzed. We conclude our work by considering some elements that should be observed in order to improve the training process so that it will lead to the training of dental surgeons able to act within a new perspective, that of health promotion.
\end{abstract}

Key words: Dental education; health promotion; dental faculty

\section{Resumo}

O presente artigo apresenta um retrato da formação dos cirurgiões-dentistas, objetivando contribuir com a atual transformação curricular dos cursos de Odontologia brasileiros, considerando as necessidades do Sistema Único de Saúde. Para tanto, resgata o modelo de atenção vigente na saúde e enfatiza que para o cumprimento de seus princípios é necessário mudar primeiramente a formação dos formadores, isto é, dos professores que atuam na educação superior na área odontológica. Nesse sentido, discute alguns aspectos da formação desses docentes, assim como a instituição das Diretrizes Curriculares Nacionais nos Cursos de Odontologia. Analisa, ainda, o perfil profissional do egresso das Faculdades de Odontologia brasileiras e conclui considerando alguns pontos que devem ser respeitados para que se agregue valor ao processo de formação, de modo que este possa dar conta de formar cirurgiões-dentistas capazes de atuar dentro de uma nova perspectiva, a promoção da saúde.

Palavras-chave: Educação em Odontologia; promoção da saúde; docentes de Odontologia

\author{
Vivianne Coelho Noronha Diógenes ${ }^{a}$ \\ Georgia Costa de Araújo Souzab \\ Gustavo Barbalho Guedes Emilianoc \\ José Ferreira Lima Júniord \\ André Alencar Suliano ${ }^{\mathrm{e}}$
}

\footnotetext{
a Programa de Pós-Graduação em Saúde da Família, Universidade Regional do Cariri (URCA), Crato, PE, Brasil

b Departamento de Odontologia, Universidade Federal do Rio Grande do Norte, Natal, RN, Brasil c Departamento de Odontologia, Universidade do Estado do Rio Grande do Norte (UERN), Caiacó, RN, Brasil

¿Escola Técnica de Saúde de Cajazeiras, Universidade Federal de Campina Grande (UFCG), Cajazeiras, PB, Brasil

e Faculdade de Medicina de Juazeiro do Norte (FMJ), Juazeiro do Norte, CE, Brasil
}

Correspondence:

Georgia Costa de Araújo Souza

Rua Joaquim Araújo Filho, 1440 - Bairro Lagoa Nova Natal, RN - Brasil

59063-120

E-mail: georgia_odonto@yahoo.com.br 


\section{Introduction}

Brazilian higher education is presently undergoing intense changes; these changes are necessary in order for it to fulfill the closely related demands of society and those of the current Unified Health System (SUS - Sistema Único de Saúde). Teamwork, health promotion, disease prevention, social and epidemiological awareness and the planning of health activities are, among others, essential elements that healthcare system workers should master.

Because of these needs, we believe that university students must graduate with such goals whether their training occurs in a private or in a public institution. However, in the health domain in particular, the educational process does not always follow this path. Historically, the working profile of Brazilian graduates was based on assistance and was oriented toward the private health care market because this was the primary way in which health workers, and dental surgeons in particular, could become professionally integrated. Such professionals generally performed their tasks according to a hegemonic health care model called Flexner's model of scientific medicine; this model is marked by biologism, individualism, mechanism, healing and specialism (1-3).

Due to its high cost and low performance and because it does not fully address health problems of the population, Flexner's model is ineffective and inefficient; nevertheless, Brazilian Dentistry still applies this model both in education and in professional practice (3). New models have, however, been presented in the past by several countries, international organizations and communities that demonstrate widespread concern in relation to public health. These models include the following:

- the Lalonde Report, published in Canada in 1974, which considered the reference framework for the behaviorist trend in modern health promotion (4);

- the Alma-Ata Declaration, issued at the end of the International Conference on Primary Health Care held in Kazakhstan in 1978, which discussed elitism in medical practice and the inaccessibility of medical services for large populations (5);

- the Ottawa Charter, a reference for the new trend in health promotion and the official document of the $1^{\text {st }}$ International Conference on Health Promotion held in Canada in 1986 (4);

- the $8^{\text {th }}$ National Health Conference, held in Brazil in 1986 (6), at which the Brazilian Health Reform Movement laid the foundations of the public Unified Health System (SUS), which would be defined by article 198 of the Brazilian Constitution of 1988 (5).

Despite the existence of these progressive models for health care, and notwithstanding the fact that the private medical care model has proven to be a failure in promoting population health, Flexner's paradigm, on which the education of professionals and health care services was historically based, continues to exert a strong influence (1).

Through SUS, an alternative model, Health Control, fostered by public health concerns, is gradually being applied to everyday practice in health services. In contrast to some of the features of Flexner's model, SUS aims at preventing disease and promoting health (7). In order to consolidate these improvements, a series of changes in health professional training are necessary, because, ultimately, a graduate's modus operandi directly derives from his or her training process.

Here, we will consider the Dentistry training process, keeping in mind that the tasks of this profession have in the past been particularly focused on technique, diseases, cure and assistance, with little consideration of preventive measures, the latter usually only being developed in particular cases (8). We will discuss the current training of dental surgeons, the participation of instructors in such training, and the SUS requirements, emphasizing the need for integration of the dental training process into the network of health services.

\section{Training of Dentistry faculty}

In order to work efficiently in the current complex market, dental surgeons first require integral training based on the Dentistry National Curricular Guidelines (DCN) that establishes the following professional profile: "dental surgeon, global professional, humanist, critical and reflective, in order to perform at all health care levels with technical and scientific rigor. Trained in the practice of oral health activities for the population, based on legal ethical principles and the knowledge of the economic and socio-cultural reality of the environment, with a view to the transformation of reality for the benefit of society" (9).

Considering this required profile, we ponder the following questions: is Dentistry faculty prepared to train such dentists? How does interdisciplinary training occur in the Brazilian dental schools? Is the fragmentation observed in the past still present within the training process of dentists? How does the training of such professionals relate to their performance? We begin our analysis by observing that changing methods in Dentistry teaching during the last century allow us to conclude that technical concerns about the existence of a highly sophisticated and elitist professional practice have not been overcome (10). According to Vale (1957), quoted by Secco and Pereira (10), students already recognized the need for qualified teaching during the 1950s; however, at that time, this recognition failed to challenge the academic context of Dentistry. The image of Dentistry faculty as highly successful liberal professionals was enough to legitimate their didactic-pedagogic competence. Only in the 1970s, with the implementation of postgraduate courses, the requirement for titles obtained in such courses and public selection processes, did the training of faculty begin to be questioned (10). Raldi et al. (11) corroborate this fact, stating that not long ago, Dentistry professors stood as specialists in their field of knowledge, and that this was a criterion for their selection and hiring. Moreover, many had no educational or pedagogic experience.

The implementation of DCNs in Dentistry courses (9) inaugurated a new period in the university field. Thereafter, 
a search for new paths to face the challenge represented by the elaboration of pedagogic projects within Dentistry courses, together with curricular changes and the professionalization of the training task (10) took place. These changes were spurred by the recognition that the qualification of faculty is necessary to build the new profile of the dental surgeon (12).

We should stress that even now, qualified faculty are not adequately prepared to perform their tasks, since several stricto sensu postgraduate courses in Dentistry overvalue specific knowledge and research, instead of the didacticpedagogic background of the future teacher. Also, because most of their postgraduate study is confined to restricted areas, Masters and Doctors frequently do not manage to successfully articulate the know-how of their field of knowledge to others. This leads to the same type of fragmentation previously observed. Therefore, even when qualified, current teachers sometimes infuse the training process of their students with no interdisciplinary action or activity whatsoever, thus fragmenting the education into isolated topics that are disconnected from social reality and community dental health needs.

With respect to this idea, Lima Júnior et al. (13) point out that in both theory and practice, the teaching of correlated topics occurs in an unarticulated way. For example, faculty generally devotes most of their in-class time to the contents of their specialty, broadening the discussion to treat some extra topics, while others are completely ignored, while at clinics, instructors do not take responsibility for patient treatment or for the integral training of students; on the contrary, they commit themselves to specific knowledge. This approach contrasts with the need of students to master every specialty in order to be able to treat their patients integrally. According to Silveira (14), neither the academic master nor the doctorate, each of which devote 60 to 90 hours to teaching methodology or didactics per curriculum, is sufficient to fulfill the requirements of a teaching training not limited to specialization. Moreover, the quality of such pedagogic training must be monitored to ensure the technical-scientific capacity of the instructor and in order to apply the best didactic-pedagogic resources in the teachinglearning process. Secco and Pereira (10) note that the stricto sensu postgraduation constitutes a privileged context within which to discuss the challenges of training faculty, whether teaching future professionals or those already in service who act in community dental programs, in oral health promotion and prevention practices and in the continuing education of professionals.

However, changes in the university context are complex and require technical and political support, which must be obtained through cooperative efforts between the Education and Health Departments. These changes can provide training for educators as well as training activities and debates among concerned sectors, that is, faculty, students, services and users (15).

Convincing faculty to reorganize themselves may be the most difficult aspect of the process of modifying current university practices. The current educational context in universities requires from faculty a commitment far beyond the topic taught. Along with articulation with health services, population needs, and students' technical, ethical, political, cultural and social education, interdisciplinary work is rationally necessary. It follows that instructors must first experience the dental surgeon profile promoted by the national curriculum guidelines so that they can share it with students, thus promoting their integral training.

Unfortunately, not all teachers are committed to the integral education of their students. This fact reduces the chances of reaching the target currently set for Dentistry courses. Worse, it leads to training identical to its traditional form, because most pedagogic projects for courses are not produced collectively.

According to Garbin et al. (16), we should be concerned about the fact that current professionals are still trained in a way that promotes the individual and healing approach and that renders many of them incapable of going beyond the cabinet room to propose community diagnoses and interventions within an integrative approach; thus, "Flexner's model of Dentistry teaching" remains in use in most dental courses in Brazil.

Learning must evolve and cease to be a simple transmission of routine practices. The teacher can no longer be someone who transmits information that students copy, memorize and show they've "learned" through correct answers in exams. Instructors must be aware of their importance in the learning process, and try to use all resources and means to reach their targets (17).

Active teaching-learning methods, with a view to students' difficulties and challenges to be overcome, are implied in the university education process. Faculty should act as facilitators and counselors in students' construction of knowledge and promote active participation by students, so that students quit the role of passive receptors to become actors and chief characters in charge of learning $(9,16,18)$.

\section{Training of dental students within the SUS context}

The progress in the Brazilian health system during the last few years has led to the need for specialized training or requalification of professionals involved in Dentistry (19). Under the Unified Health System (SUS), the training of dental surgeons must go beyond techniques, since their working process is more complex when compared to that of private practice. In addition to the skills mastered by dentists who act in the service market (private clinic), other skills are required in order to offer a qualified public professional performance (20).

Moysés (21) states that it is essential to build a working force in Dentistry that is SUS-oriented and to work within the family-oriented approach of the Family Health Strategy (ESF). Primary care dental surgeons are invited to reconsider their practices so as to assume a new role in Public Health Dentistry. Such professionals have a leading role to perform 
in community care. This role includes identifying beliefs detrimental to health, promoting oral examination of children and adults at home, giving advice on places to get help, training community agents and assistants (ACDs and THDs), assisting constant education of colleagues, acting as oral health educators within multidisciplinary and multiprofessional teams, and participating in collective educational actions (groups, schools, local health councils and associations) relating to life style, the use of fluoridated water and orientation to oral hygiene. Moreover, we cannot forget the necessity of oral health regeneration practices, which are urgently required due to the great needs and demands of the population (22).

In this context, we note that the SUS cannot continue consuming human resources in an effort to "(de)construct" inadequate professional profiles by means of training courses aimed at providing what was missed in undergraduate courses, since universities do not "recall" the "products" launched in the working market (21).

The care model currently fostered thus faces a huge challenge, that of breaking with health practices already established in all services. In order to do so, besides (re) organizing curricular graduation components, it is necessary to call health students'- particularly dental students' attention to commitment to the population. This will include making students aware of the necessity of extrapolating the biological limits of classic epidemiology triangulation, as the lack of proper use of this technique has accounted for disease emergence for far too long (23).

The Dentistry Graduation Course Curricular Guidelines (9) state that the training of dental surgeons should consider the current national health system, integral health care within regional and hierarchical reference and counterreference systems, and teamwork. Thus, the SUS must represent the curricular basis of dental courses and aim to train professionals focused not only on patient assistance but also, and perhaps primarily, on a good quality of life for the population (24).

In Zanetti's view (20), in such a context of multiple challenges, dental surgeons have shown a huge inability to cross the boundaries of particular (individual) action so as to reach collective action. For this reason, we may observe that even now, professionalization does not adequately prepare dental surgeons to appropriately perform their tasks in public services. In such a view, academic students learn and practice "state-of-the-art" Dentistry; when graduated, many will work in the SUS, where often only limited resources are available and where, moreover, their participation is required in order to help the community. In addition, the practice of health promotion and activities leading to prevention of oral diseases has been historically neglected in the training process, because students believe this is basic and seek to go into sophisticated techniques in depth.

Lucieto (25) states that difficulties arise when students graduate and begin working in the SUS, particularly within Family Health Strategy, where a practice chiefly focused on preventive-promotion activities is required. Because these are extra-clinical activities, professionals feel unable to perform them adequately. It should also be borne in mind that such actions are mediated by governmental (collective) processes of decision-making and realization. These processes imply high uncertainty, political disputes, conflicts and several options for decision-making, among others.

Targeted intervention in the training process is consequently required so that graduation programs may shift the training axis from a focus on individual assistance toward a contextualized training process that takes into account the social, economic and cultural dimensions of the population and prepares professionals to face the problems of community health and disease. This requirement emphasizes the importance of the role of the SUS in stimulating changes in the training of health professionals according to its interests and needs. This will in turn facilitate modification of training in universities that promotes the approximation between professional training and requirements for high-quality, more effective and egalitarian health care (26).

In order to reduce the gap between academic training and the working field, university extension activities were created. The goal of such activities is to reorient pedagogic projects and to contribute to the development of professionals aware of community health needs and who seek multidisciplinary integration between preventive and healing measures, theory and practice, and teaching and service (27). According to Galassi et al. (17), the participation of today's students, who will tomorrow be professionals, in external activities during graduate study results in their being better prepared to work in the community, particularly in health services, due to previous contact opportunities and development of a conception of community social awareness.

Such extension activities, together with in-service training in public facilities, through articulation with SUS administrators, should become increasingly frequent in university courses, in order to reach a new teaching approach, based on the triangulation of university, community and service, thus contributing to build a sensitive professional, committed to social reality.

The development of the teaching-learning model required by the needs of the SUS must not remain confined to narrow academic areas, but ought to be extended by institution authorities with the support of Dentistry orders and colleges in order to reach all possible areas, so as to represent a meaningful university movement toward transformation (26).

Finally, we believe the mastering of the National Curricular Guidelines by educators is essential, together with their application in universities. This is a sine qua non for enabling dental surgeons to act according to health control model principles in the medium term, with a stress toward preventive and health promotion activities, notwithstanding welfare aspects.

\section{Final considerations}

In order to train professionals who possess the profile currently fostered by the health model in force in Brazil, 
faculty and dental courses should promote real changes in the education process, with emphasis on the aspects of training required by the needs of the Unified Health System (SUS). In addition, the training of Dentistry educators should be reviewed so as to establish an adequate pedagogic background.

To overcome the current fragmentation of dental surgery training, multidisciplinary articulation and curricular integration are required. The latter, through teaching-training methods that are both SUS-based and focused on students, calls for a new pedagogic model that allies technical excellence and social relevance, encourages partnerships between the university, health services and the population, favors education in critical active subjects, fosters awareness of social reality and permanent education needs, and is committed to population welfare.

\section{References}

1. Mendes EV. A evolução histórica da prática médica suas implicações no ensino, na pesquisa e na tecnologia médicas. Belo Horizonte: PUC-MG/FINEP; 1984.

2. Araújo LU, Roncalli AG. O Sistema Único de Saúde e os modelos assistenciais: das propostas alternativas à saúde da família. In. Ferreira MAF, Roncalli AG, Lima KC. Saúde Bucal Coletiva: conhecer para atuar. Natal: EDUFRN; 2004. p. 261-275.

3. Pereira DQ, Pereira JCM, Assis MMA. A prática odontológica em Unidades Básicas de Saúde em Feira de Santana (BA) no processo de municipalização da saúde: individual, curativa, autônoma e tecnicista. Ciênc Saúde Coletiva 2003;8:599-609.

4. Carvalho SR. Os múltiplos sentidos da categoria empowerment no projeto de Promoção à Saúde. Cad Saúde Pública 2004;20: 1088-95.

5. Brasil. Conselho Nacional de Secretários de Saúde. Sistema Único de Saúde. Coleção Progestores - Para entender a Gestão do SUS. Brasilia: CONASS; 2007.

6. Brasil. Ministério da Saúde. Relatório Final da $8^{a}$ Conferência Nacional de Saúde. Brasília: Ministério da Saúde; 1986.

7. Ciuffo RS, Ribeiro VMB. Sistema Único de Saúde e a formação dos médicos: um diálogo possível? Interface Comun Saúde Educ 2008;12:125-40.

8. Narvai PC. Saúde bucal coletiva: caminhos da odontologia sanitária à bucalidade. Rev. Saúde Pública 2006;40:141-7.

9. Brasil. Diretrizes Curriculares Nacionais para o curso de graduação em Odontologia. Resolução CNE/CES 3/2002. Diário Oficial da União, Brasília, 4 de março de 2002. Seção 1, p. 10.

10. Secco LG, Pereira ML. Formadores em odontologia: profissionalização docente e desafios político-estruturais. Ciênc Saúde Coletiva 2004;9:113-20.

11. Raldi DP, Malheiros CF, Fróis IM, Lage-Marques JL. O papel do professor no contexto educacional sob o ponto de vista dos alunos. Rev ABENO 2003;3:15-23.

12. Péret $A C$, Lima ML. A pesquisa e a formação do professor de Odontologia nas políticas internacionais e nacionais de educação. Rev ABENO 2005;3:65-9.

13. Lima Jr JF, Emiliano GB, Souza GC. A dicotomia em odontologia: o docente especialista formando o discente generalista. Rev ABENO 2008;8:38-9.

14. Silveira JL. Diretrizes curriculares nacionais para os cursos de graduação em odontologia: historicidade, legalidade e legitimidade. Pesqui Bras Odontopediatria Clin Integr 2004;4:151-6.
15. Costa IC, Araúio MN. Definição do perfil de competências em saúde coletiva a partir da experiência de cirurgiões-dentistas. Ciênc Saúde Col [serial on the Internet]. [cited 2008 Sept 25]. Available from: http://www.abrasco.org.br/cienciaesaudecoletiva/artigos/ artigo_int.php?id_artigo $=1912$.

16. Garbin CA, Saliba NA, Moimaz SA, Santos TS. O papel das universidades na formação de profissionais na área de saúde. RevABENO 2006;6:6-10.

17. Galassi MA, Barbin EL, Spanó JC, Melo JA, Tortamano N, Carvalho AC. Atividades extramuros como estratégia viável no processo ensino-aprendizagem. Rev ABENO 2006;6:66-9.

18. Díaz Bordenave J, Pereira AM. Estratégias de ensino-aprendizagem. 14. ed. Petrópolis: Vozes; 1994

19. Saliba NA, Moimaz SAS, Chiaratto RA, Tiano AVP. Utilização da metodologia PBL em Odontologia: descortinando novas possibilidades ao processo ensino-aprendizagem. Rev odonto ciênc 2008;23:392-6.

20. Zanetti CHG. Odontologia: habilidades e escolhas. [Internet]. [cited 2008 Nov 12]. Available from:http://www.saudebucalcoletiva.unb. $\mathrm{br} /$ oficina/mercado/estrutural/habilidades.htm.

21. Moysés SJ. Políticas de saúde e formação de recursos humanos em odontologia. Rev ABENO 2004;4:30-7.

22. Aerts D, Abegg C, Cesa K. O papel do cirurgião-dentista no Sistema Único de Saúde. Ciênc Saúde Coletiva 2004;9: 131-8.

23. Oliveira ET, Lima Júnior JF, Soares FNCS, Maia ER. A Odontologia Social no contexto da Promoção da Saúde. Rev Bras Promoção Saúde 2008;21:75-9.

24. Tavares GR, Taveira GS, Véras Neto L, Padilha WW. A participação da comunidade nas clínicas das instituições de ensino odontológicos (EIOs). Pesqui Bras Odontopediatria Clin Integrad 2005;5: 179-84.

25. Lucietto DA. Percepção dos docentes e reflexões sobre o processo de formação dos estudantes de Odontologia. [dissertation] Rio de Janeiro (RJ): Faculdade de Saúde Pública; 2005.

26. Campos FE, Ferreira JR, Feverwerker L, Sena RR, Campos JJB, Cordeiro $\mathrm{H}$, et al. Caminhos para aproximar a formação de profissionais de saúde das necessidades da atenção básica. Rev Bras Educ Med 2001 ;24:53-9.

27. Medeiros Jr A, Alves MS, Nunes JP, Costa IC. Experiência extramural em hospital público e a promoção da saúde bucal coletiva. Rev Saúde Pública 2005;39:305-10. 